\title{
Fine-Tuning Shari'ah Compliance in Malaysia through Regulations ${ }^{1}$
}

\author{
Sheila Ainon Yussof \\ International Islamic University, Malaysia
}

\begin{abstract}
Shari'ah compliance is a cardinal principle in Islamic finance which must be observed by Islamic financial institutions in Malaysia and other emerging markets as it provides the original basis (or raison d'etre) for establishing a faith-based and commercially viable alternative financial system. In fact, it is this unique and distinctive ethico-religious feature that distinguishes Islamic finance from conventional finance. The imposition of this additional requirement makes it necessary for Islamic financial service providers to operate according to Shari'ah [the law and objectives of the Shari'ah (maqasid al-Shari'ah)]. Prominence should not only be given to legality of transactions, financial performances and profitability; these technical and commercial parameters must also be enhanced by realization of the maqasid of public good. To gauge whether IFIs are complying with Shari'ah, the compliance itself must be measured from end- to-end to cover the whole spectrum of activities: from product development, operational process, human resource management, information technology application systems, to dispute resolution mechanisms. The integrated and comprehensive approach of Malaysia comes highly recommended as it will reflect the holistic worldview of Islam. Protection of consumers, environmental protection, securing and realization of public benefit, should therefore form the central theme of Shari'ah compliant finance. When applied to banks and takaful operations, it necessitates the business organisations to fine-tune Shari'ah compliance to a more humancentric tenor or orientation in its rule application, whilst achieving macro-economic goals of economic prosperity and social justice. The risk of Shari'ah non-compliances can be costly to the IFIs as it will lead to invalidation of contract resulting in non-halal income and possibility of legal suits from aggrieved customers and harming industry's credibility. This paper highlights the legal and regulatory measures undertaken by Malaysia to fine-tune Shariah compliance. It gives greater focus to the general issues relating to Shari'ah compliance within the Takaful industry and the challenges of control. Recommendations are made for stakeholders to operationalize the Maqasid al-Shari'ah through the inclusion of an ethical and moral parameter to complement legal compliance, and preparing the industry to move towards a Shariah-based operating environment.
\end{abstract}

Key words: Shari'ah compliance, maqasid al-Shari'ah, fine-tuning, human-centric, ethical parameters, protection of consumers, Islamic Financial Services Act 2013

\section{Introduction}

Shari'ah compliance encompasses the principles and philosophical foundation and a raison d'etre for establishing a faith-based financial system in Malaysia. Indeed, it is this unique and distinctive ethico-religious feature that distinguishes Islamic finance from conventional finance. Islamic financial service providers are required to operate according to the rules and principles of Shari'ah to ensure validity and enforceability of contracts as the financial impact of Shari'ah non-compliances can be costly to business operations. The invalidation of contract can lead to other repercussions such as the earning of non-halal income, the threat of legal suits from aggrieved customers and reputational risk. Being faith-based, IFIs should endeavor to reap the blessings (or barakah) from Allah by adhering strictly to Divine laws in the Qur'an and the practices of the holy prophet. The basic prohibitions of riba', gharar and maysir must be observed; the rules or pillars of each Islamic contracts must not be tweaked to resemble conventional instruments in their modus operandi. There must be a balance between "form" and "substance" where legal validity of a contract must confer benefit to consumers in accordance with the spirit of Islamic law (Maqasid al-Shariah).

A wasatiyyah approach must be adopted and maintained at all times by IFIs. The other Shariah principles that must be complied with are discouragement of the production of goods and services that are harmful to

"Part of this article has appeared in a book chapter with a slightly different title "Fine-tuning Shariah Compliance in Takaful Audit". The editors of the book have given permission to present and publish the modified version.

Corresponding Author: Sheila Ainon Yussof, e-mail: syussof@yahoo.com

c COMSATS Institute of Information Technology Lahore, Pakistan. 
human, conducting business in an ethical manner, promoting entrpreneurship and socio-economic justice through sadaqah, zakat and waqf. This integrated and comprehensive approach should reflect the holistic worldview of Islam. Securing and realization of public benefit, protection of consumers, environmental care, should therefore form the central theme of Shari'ah compliant financing. This faith-based financing is now globally accepted as a category of investment or a financial transaction, unique in its form, as it requires an additional step: the endorsement by Shari'ah scholars who certify products that are legal, authorized or pure pursuant to Shari'ah. Thus for Islamic financial systems in Malaysia, whether a given transaction is deemed Shari'ah compliant or not, depends on the approval of scholars sitting on the Shari'ah board, at IFIs level, known as the Shari'ah Committee.

To gauge whether IFIs are complying with Shari'ah, the compliance itself must be measured from end- to-end, in a holistic and integrated way, to cover the whole spectrum of activities: from product development, operational process, human resource management, information technology application systems, to dispute resolution mechanisms. IFIs in Malaysia in monitoring and measuring Shari'ah compliance, should reflect in their operations, the multidisciplinary and integrative character of Islamic finance: it should not, in carrying out its operations, make a clear dichotomy between law and economics, or compartmentalizing the rules of Shari'ah from the objectives of Shari'ah, and fulfilling one aspect of compliance and not the other. For instance, the muamalat rules on halal and haram, riba' and gharar do not only provide the legal parameters for the prescribed validity of Islamic transactions but are also meant to serve the economic objectives of fair trading, accountability, transparency and social justice.

Likewise, when auditing products, operations and IT systems, the public must be assured not only on the technical aspects or validity of instruments but also on whether these are beneficial and not harming consumers in any way in relation to their investments. All in all, the audit must be holistic and integrated, where all the aims and operations, business, affairs and activities must comply with any ruling of the Shari'ah Advisory Council (SAC) in those aforementioned areas, as the SAC is now entrusted with the task of issuing Shari'ah standards.

Thus IFIs will not only be required to undertake a comprehensive audit (end-to-end) but must also adhere to those standards set by SAC. It is hoped that IFSA in giving greater attention to the rules of Shari'ah contracts will eventually give prominence to the maqasid impact of the rules, bringing it closer to the Shari'ah, or a fuller compliance to Shari'ah where legal, ethical and socio-economic aspects of the contract are fulfilled according to the noble objectives of the Quran and Sunnah, packaged in the muamalat principles, to achieve economic prosperity, social justice and falah (happiness). If Shari'ah non-compliant risk is not managed, monitored and measured closely through a robust review and audit and comprehensive Shari'ah governance framework, it will tarnish the credibility of the industry and affecting the long term sustainability of Islamic finance.

Lastly, with the introduction of the Islamic Financial Services Act 2013 (IFSA) in Malaysia, any noncompliances with Shari'ah will be regarded as a serious breach of the provisions of this omnibus legislation which will not allow any officers (CEO, Board of Directors, management and Shariah Committee) go unpunished. Although there are degrees of adherence to Shari'ah in our personal lives, there must be a consistent engineering and fine-tuning of Shari'ah compliance within the Islamic finance industry to ensure uniformity of rules application. Islamic financial institutions are under a duty to comply with one common set of divinely guided rules and principles of Shari'ah or face sanctions as it concerns public funds.

\section{Malaysia's Approach to Shari'ah Compliance}

Malaysia has a structured approach to Shariah compliance. Firstly, it must be a comprehensive adherence to the Shariah. As Shari'ah compliance means adherence, compliance, and obedience to all that Allah (swt) ordered humans in the Qur'an and obeying what His Prophet (pbuh) has ordered through Hadith sahih, Islamic financial institutions in Malaysia must reflect those criteria. Thus they are now legally required under section 28 of the Islamic financial Services Act, 2013 to strictly comply with Shariah in all its aims and operations, business, affairs and activities. This means a holistic, integrated or end-to-end compliance from product development to operational process, IT application system, human resource development, marketing and advertising, accounting and auditing and dispute resolution mechanisms.

Secondly, the compliance to Shari'ah must be balanced, as compliance must not only be to the "letter" of the 
law but Islamic financial institutions must also observe the "spirit" of the law. This means that Islamic financial institutions must adhere to Shariah rules relating to fiqh, qawaid and fatwa, but at same time fulfill the objectives of the Shari'ah (Maqasid al-Shariah) to protect faith (Islam), life, intellect, progeny and wealth. Thus from the operational perspective, Shari'ah compliance can be defined as fine-tuning process to ensure that all financial transactions, investment and the entire business operations conform to Shari'ah rules and principles, which should also include fulfilling the objectives of Shari'ah in promoting human welfare through protection of stakeholders' interests, especially consumers. Legality of transactions must be accompanied by conferment of benefit to humanity; it must prevent harm. And we are also required to give what is lawful and good as exhorted in the Qur'an which applies to Islamic financial products and services. Islamic financial business may be commercial in nature but industry players must have a God-centric conscience to ensure justice, equity and fair play. It is recommended here that existing compliance standards should be fine-tuned to move towards a more human-centric rule application to achieve social justice. Commercial goals that are set to achieve economic prosperity should follow the Islamic rules on wealth generation and protection as otherwise it will not accomplish the goals of distributive justice. In Malaysia's effort to fine-tune Shari'ah compliance, it is asserted here that prominence should be given to realization of the maqasid of public good. Shari'ah compliance should not be confined to a mere adherence to legal forms (legality of transactions), financial performances and profitability goals. It should be a holistic approach to shari'ah compliance.

Thirdly, it must be regulated, monitored, measured and independently assessed to give full disclosure and provide objective assurance to the public that the Islamic financial institution is complying with Shariah in a holistic and integrated way so as to preserve the integrity of Islam and gain public trust. From the regulatory perspective and under the newly introduced law on Shari'ah compliance through the Islamic Financial Services Act of Malaysia (IFSA, 2013), Islamic financial institutions are under a legal duty to ensure compliance with Shariah. It is in this very legislation that Shariah compliance is legally defined under 28 (2) to be a compliance with any ruling of the Shariah Advisory Council. It clearly shows Malaysia's progressive effort in providing a comprehensive standard as to what constitutes Shari'ah non-compliance and what punishment will be meted out for any violations of its legal provisions. Thus under section 28 (1), it shall be the duty of institutions to ensure compliance with Shari'ah in its aims and operations, business, affairs and activities. And it shall be Shari'ah non-compliant if IFIs do not comply with any ruling of the SAC in respect of that aims and operations, business, affair or activity [section 28 (2)]." Consequently, any non-compliances with Shari'ah and the ruling of the Shariah Advisory Council will be regarded as a serious breach of the provisions embedded in the omnibus legislation. The Shari'ah committee as an oversight body for Shari'ah compliance at the institutional level will not be spared from this accountability just as the board of directors and management will be collectively accountable. And if found guilty of any violations of the law governing Shari'ah compliance, the would-be offenders will face a hefty fine of RM25 million or 8 years imprisonment or both, where on conviction, a new breed of corporate criminals will be created.

IFIs must now diligently comply with Shari'ah to support the main goals or principal regulatory objectives of IFSA which are to promote financial stability, ensure shari'ah compliance and protect consumers. IFSA has also empowered the Central Bank of Malaysia to take civil and criminal actions against offenders which makes the Shari'ah compliance process more structured and definitive. The Central Bank of Malaysia through its SAC is also empowered under section 29 to specify standards on Shariah matters (in respect of the carrying on of business, affair or activity\} as well as on Shariah governance which gives some form of legal recognition to an earlier directive on shariah governance- the Shariah Governance Framework 2011. Section 29 (1) requires ascertainment of Islamic law by the SAC whilst section 29 (2) does not require so, However section 29 (1) has a greater liability, where it provides that any person who fails to comply with any standards, commits an offence and shall, on conviction, be liable to imprisonment for a term not exceeding eight years or to a fine not exceeding twenty five million ringgit or to both.

\section{Shari'ah Compliance Regulations in Malaysia}

On product structuring, and during the initial stages of its development, the Islamic finance industry in Malaysia had focused mainly on financial engineering ${ }^{1}$ (or replication of conventional instruments) instead of contractual engineering. Contractual engineering (as opposed to financial engineering) involves the identification of permissible combinations and modifications of traditional contracts to make them Shari'ah compliant. It was propositioned by a scholar that when new contracts are developed through contractual engineering and economic innovation, it will realize the economic/social aims of Shari'ah. There will be no 
room to circumvent the shari'ah, as is done under the "Shari'ah Conversion Technology".

Subsequently, in 2013, IFSA introduced a 'Contract-Based' Regulatory Framework so as to achieve the compliance objective and to ensure that every Islamic contract offered in the market must reflect its true nature. The contract based regulatory framework is also designed to address sound practice principles and BNM's expectations for effective risk management, governance, disclosures, and appropriate legal and accounting treatments for key Islamic contracts that are necessary to ensure compliance with Shari'ah under different Islamic contracts.

The Act provides not only a strong legal foundation for end-to-end shariah governance and compliance, but also a comprehensive regulatory framework for Islamic finance in Malaysia which reflects the specificities of the various types of Shariah financial contracts, and supports the effective application of Islamic contracts in the offering of Islamic financial products and services - from the entering into a contract to the resolution of a failed Islamic financial institution. This represents a significant step forward in aligning legal and regulatory principles with Shariah precepts. To this end, Malaysia can provide a global benchmark for other countries to follow in the evolution of more comprehensive regulatory frameworks that promote greater legal and operational certainty in Islamic finance.

Diagram 1: Contract-Based Regulatory Framework

\section{Islamic finance}

Islamic banks conduct financial intermediation functions using Shariah contracts Distinct Risk and Reward Profiles based on Shariah Contracts

End-to-End Shariah Compliance under IFSA 2013

\begin{tabular}{|c|c|c|c|}
\hline Shariah Standards & $\begin{array}{l}\text { Operational } \\
\text { Standards }\end{array}$ & $\begin{array}{l}\text { Oversight } \\
\text { Functions }\end{array}$ & Resolutions \\
\hline $\begin{array}{l}\text { Compliance with } \\
\text { fundamental } \\
\text { requirements of } \\
\text { respective Shariah } \\
\text { contracts }\end{array}$ & $\begin{array}{l}\text { Strengthened risk } \\
\text { management, } \\
\text { governance, } \\
\text { transparency and } \\
\text { disclosure, market } \\
\text { conduct, and other } \\
\text { operational aspects } \\
\text { of applying Shariah } \\
\text { standards }\end{array}$ & $\begin{array}{l}\text { Codification of the } \\
\text { role of the Shariah } \\
\text { Committee and } \\
\text { Board of Directors } \\
\text { of financial } \\
\text { institutions in } \\
\text { ensuring Shariah } \\
\text { compliance }\end{array}$ & $\begin{array}{l}\text { Priority of } \\
\text { payment reflective } \\
\text { of underlying } \\
\text { Shariah contracts }\end{array}$ \\
\hline
\end{tabular}

Source: Bank Negara Malaysia

As discussed earlier on, the SAC is mandated under section 29 (1) and (2) of IFSA 2013 to specify standards on Shariah matters. In this regard, the CBM may specify Shariah standards for key Islamic contracts in consultation with the SAC. The standards serve to define essential features of the underlying Shariah principles that are adopted by IFIs, while enhancing certainty and public confidence in Islamic financial transactions. The CBM issued the Shariah Standard on Mudarabah in October 2012, while Shariah standards on murabahah, musharakah, ijarah, wadiah, hibah, salam and istisna' are a "work-in-progress" efforts. To support the effective implementation of Shariah standards and ensure compliance by IFIs, CBM also issues guidance or Operational Standards on Shariah matters. Such guidance and operational standards address sound practice principles and CBM's expectations for effective risk management, governance, disclosures and appropriate legal and accounting treatments for key Islamic contracts that are necessary to ensure compliance with Shariah under different Islamic contracts.

Thus under the contract based regulatory framework, the required standardisation of contracts will ensure uniformity of practice amongst IFIs. Once the exposure draft has elicited comments from relevant experts in the industry it will become the SAC's established 'Shari'ah Standards' for IFIs to adhere; the SAC here playing 
the role of standard setter for the Malaysian Islamic finance industry on what constitutes Shariah compliance. This will ensure that every Islamic contract used will carry a common genetic printing to ensure consistency in its application. Using the contract of Musharakah Mutaanaqisah for home financing as an example, what is offered by Bank Islam Malaysia Berhad (Malaysia's first Islamic Bank) for instance will have the same rules and modus operandi as that by Saadiq (Islamic subsidiary of Standard Chartered Bank). The differences should only be on the relative quality of customer relations and service management and the benefits offered to customers in a Shari'ah compliant manner.

\section{Rationale for Adopting the Maqasid Paradigm}

In the reservoir of scholarly works on Islamic jurisprudence, the Shari'ah has been classified under four areas of study. In using the pyramid to illustrate its order of importance, scholars have placed the Maqasid alshari'ah (objectives of the Shari'ah) at the top, followed by Qawaid (legal maxims) and thereafter Usul-alFiqh (principles deriving rulings from the Shari'ah) and finally the Fatwa (specific rulings issued by scholars) as the base.Maqasid al-Shari'ah is classified under three categories in a descending order of importance, beginning with the (1) essential masalih (or daruriyyat), followed by the (2) complementary benefits (or hajiyyat) and the (3) embellishments (or tahsinniyat). The highest ranking accorded to essential masalih is due to the fact that it contributes to normal order in society as well as to the survival and spiritual well-being of individuals, so much so that their destruction and collapse will precipitate chaos and collapse of normal order in society." The five areas that need to be protected under essential benefit (daruriyyah) in order to maintain social order and stability are faith, life, intellect, family and wealth. The harmful effects of riba' for instance, must be alleviated by having a riba-'free economic system, as riba' can corrupt faith, life, intellect, family and wealth. In the area of commerce and muamalat, where wealth is generated, the Qur'an forbids exploitation, usury, hoarding and gambling, which are harmful and jeopardize the objectives of fair dealing in the marketplace. Wealth is regarded as one of the fundamental and universal principles of the Shari'ah which must be protected and preserved for economic prosperity of the Muslim ummah and the general public.

Although the maqasid is placed at the apex of the pyramid to show its importance as an all-encompassing or "umbrella" principle, there is still an "apparent dearth in its applicability or focus in the current Islamic financing structures". For instance, on product structuring, the industry is giving too much leverage on the letter of the law or the halal concerns but low priority given to the spirit of the law (for example on the protection of consumers). This has resulted in a rising incidence of liability suits and bankruptcy cases in Malaysia and causing economic hardships. In the face of such a credibility challenge, there is a need to develop Islamic products which are more in line with the maqasid. As recommended by a scholar, to enhance the credibility of the Islamic finance industry, IFIs should realign its focus to an equity-based solution combined with a focus on holistic, equitable Islamic criteria of transparency, accountability and fairness across the various facets of current best international corporate practices in fields such as Corporate Governance (CG), Corporate Social Responsibility (CSR) and others. The current industry practice of "cloning" or "replicating" conventional products and processes does not support the much awaited paradigm change. The industry should innovate and not imitate, and it must move beyond compliance. A paradigm shift is also needed where greater importance must be given to the maqasid of "wholesomeness" or purity of transactions as found in the verse of the Qur'an:"O mankind! Eat of that which is lawful and good/wholesome in the earth, and follow not the footsteps of the devil. Lo! He is an open enemy for you."

Diagram 1: Apex Position of the Maqasid in the Shari'ah Pyramid

Shari'ah recognizes maslahah (public good) and their allied doctrines of maqasid al Shari'ah (goals and

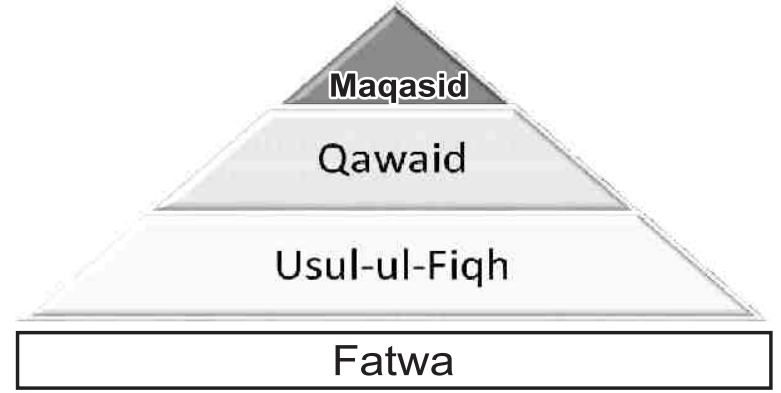

objectives of Shari'ah) to be the sources of law and judgement, fatwa-making and ijtihad ${ }^{9}$. The Islamic 
worldview itself is based on Shari'ah, where man occupies center stage in the earthly cosmos or universe rooted in a "Tawhidic paradigm" and governed by good conscience ${ }^{10}$. The Shari'ah aims at relieving people of hardships and providing them with solutions to their problems ${ }^{11}$. The sole purpose of the Shar'iah is to realize human welfare, justice and equity. This caring for all humanity with respect, compassion and just dealings is a universal message that is found in the Quran and hadith and in the writings of ulama on maslaha (public good/interest/benefit) and maqasid al- Shari'ah. IFIs are cradled within the Shari'ah system and they are required to comply with the legal and ethical principles of the Shari'ah in order to preserve the integrity of Islam. The Islamic finance industry therefore needs to comply fully with the Shari'ah, or to encapsulate all the principles of Shari'ah to the letter of the law and spirit of the law in their transactions, processes and activities.

\section{Shari'ah Compliance Regulations for Takaful in Malaysia}

In view of new developments in the legal, regulatory and Shari'ah frameworks for the TakEfful industry1 in Malaysia, namely the Shari'ah Governance Framework (SGF) 2011, the TakÉful Operational Framework (TOF) 2012 and the Islamic Financial Services Act (IFSA) 2013, there is a need for regulators to specify maqasid or ethico-religious benchmarks for the industry to adopt.

Inductive analyses undertaken by the present author of existing regulations governing TakÉful operations in Malaysia show an apparent biasness towards rule compliance. There is no robust scrutiny or methodology in place to assess the beneficial impact of the rules nor does it take into account prevention of harm to consumers and other stakeholders which are humanistic values being promoted under Maqasid al-Shari'ah.

The Shari'ah Governance framework (SGF) of 2011 requires takaful operators to have a more prudent supervision of Shari'ah compliance. The principle-based (as opposed to prescriptive-based) guidelines were to ensure TakÉful industry's comprehensive compliance with Shari'ah, but they were clearly silent on the maqasid. One of the objectives of the SGF is to gear Islamic financial institutions in Malaysia to move towards a Shari'ah-based operating environment which means "moving beyond compliance". It was also introduced to overcome past practices of imbalanced or "form over substance" compliances. The SGF did not however prescribe a specific internal shari'ah audit framework for TakÉful companies to adopt, customize and adhere to. The SGF did however provide a framework for a tripartite audit consisting of financial audit, operational audit and review audit to show the importance of having a comprehensive audit as shown in diagram 2.

Subsequently, the Takaful Operators Framework (TOF) was introduced in 2012 where a common benchmark for takaful operations was provided to ensure regulatory clarity and operational efficiency of TakÉful companies which gave some semblance of uniformity. On analysis, the TOF is seen to be more supportive of a technical audit; it did not provide ethical benchmarks to assess the beneficial impact of Shari'ah rules. It can only fulfill one aspect of Shari'ah compliance. It is recommended here that the Takaful operational benchmarks should be fine- tuned to reflect the maqasid.

IFSA 2013 as the latest piece of legislation impacting the TakÉful industry is giving prominence to Shari'ah standards, compliance, enforcement and penalties. It reinforced BNM's power to statutorily monitor and enforce Shari'ah-compliance and safeguard financial stability. The contract-based regulatory framework will ensure that the laws are reflective of the "true nature" of Shari'ah contracts (Zeti Akhtar Aziz, 2012) supportive of an effective end-to-end Shari'ah governance and compliance in the Islamic financial sector. It is here that the meaning of "true nature" of Shari'ah contracts should be defined as it is not clear whether all Islamic contracts must now reflect both the legal and maqasid requirements of the contracts. If "true nature" of Shariah contracts is defined to be inclusive of the maqasid, it can be inferred that there is now a conscious steering by the regulator to include the Shari'ah objectives of justice, equity and fair play for Islamic financial institutions to protect consumers and other stakeholders.

To summarise, IFSA has given BNM the supervisory power to issue Shar'iah Standards and Practice Guides under Section 29 of IFSA 2013. BNM is now empowered to specify Shar'iah standards for key Islamic contracts in consultation with the SAC. The principles of Shari'ah will be enforced within this framework to facilitate in the reduction of risks (legal and operational risks) in the conduct of Islamic financial transactions. 
At this juncture, the 'Exposure Drafts' have been circulated to industry experts for their comments. Although proactive measures by BNM to tighten the rules on Shari'ah compliance and governance have contributed towards legal and regulatory clarity and consistency for the operations of Islamic finance in Malaysia, ${ }^{12}$ more needs to be done to reflect the Maqasid in a TakÉful audit of its operations. Shari'ah audit should give objective assurances to the public that all the activities of the IFIs comply with Shari'ah in its fuller meaning of complying with the rules of shari'ah and the maqasid impact of the rules. It is proposed in this article that a maqasid-based audit should be considered by the industry, as it will promote benefits to humanity. It will also avoid harm and promote justice in acquiring wealth; ensure that wealth is circulated among as many people as possible. The maqasid focus would also lead to an innovative focus which will be from the fount of Shari'ah instead of replicating conventional contracts.

\section{Diagram 2 Tripartite Audit Framework for Takaful}

Source: BNM's Shariah Governance Framework (2011)

\section{Proposed Methodology to finetune Shariah Compliance through a Maqasid-based Audit}

Recently active discourses and studies have been made by academicians, scholars and industry players on the need for Islamic finance to give greater weight to the substantive or welfare dimension of the Shari'ah (or public good). It was also one of the ethos of the architects of Islamic finance that Shari'ah compliance is needed at the initial stage of its development which should later progress towards a new genre of Islamic financing products that are Shari'ah-based. This could only mean that Shari'ah-based products are not only required to be lawful but they must also be good and wholesome and fulfilling the maqasid of economic wealth of justice, clarity, growth, constancy and sustainability. In other words, there will be greater applicability or focus on maqasid-al-Shariah to define the Islamic finance industry's unique selling point (USP) and distinctive characteristics of doing business. At this juncture mention should be made on the new wave of intensifying Shariah compliance, where "wholesomeness" or "goodness", under tayyib principles found in the Qur'an are viewed to give a better assurance on industry's credibility rather than simple compliance. This section will focus on the importance of reflecting the maqasid in financial transactions, investments and business operations and the challenges of operationalizing the maqasid al-Shari'ah as an ethical parameter to ensure a fuller compliance to Shari'ah.

It is customary practice that in making independent assessments and giving objective assurances on Shari'ah compliance, auditors must be satisfied that the following requirements are fulfilled by the areas under audit:

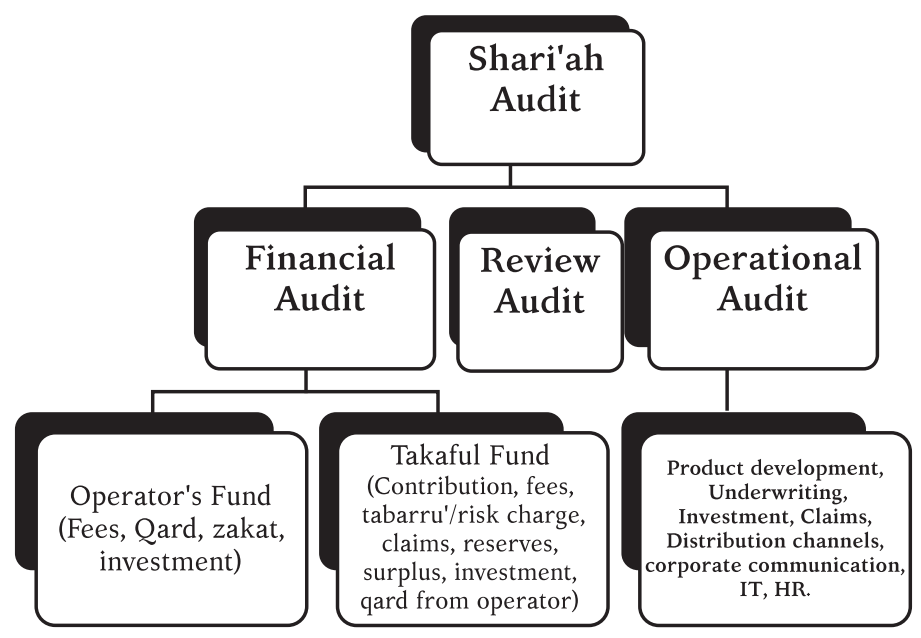

(a) Observations of prohibitions in Shari'ah law; (b) Fulfillment of the contract requirements according to Shari'ah; (3) Proper use of muamalat concepts in contracts or products. Another criterion which should be included will support the present author's proposal (4) that the areas under examination ought to satisfy the 
Maqasid or objectives of the Shari'ah.

The Screening Methodology using a Maqasid Filter

In order to operationalize the maqasid, it is proposed in this study to apply the Screening Methodology on Family Takaful operations. This methodology will ensure a holistic shari'ah compliance audit. Family Takaful is selected as it has a unique dual function: Risk Mitigation (insurance) and Wealth Generation. The methodology can also be applied to General Takaful with modifications, as Takaful itself has all the spiritual ingredients of protecting faith, life, intellect, progeny and wealth, representing a range of risks to humanity requiring mitigation. Thus to enhance existing audit which tends to be technical, the proposed Screening Methodology will comprise a two-tier screening process at the initial stage:

Table 1: The Maqasid Filter

First Filter: ("Maqasid Paradigm") Ranking or Prioritisation of Family Takaful Operational Elements According to Universal Values

Islam has the Maqasid paradigm that protects religion, life, intellect, family and wealth, where the importance of each dimension will be given priority according to the changing needs of society in respect of time and space. Before conducting the audit exercise, the proposed screening methodology will determine at this level, whether the particular TakEful operational area to be audited (underwriting, investment, etc) is an essential benefit (daruriyyah), complementary benefit (hajjiyah) or an embellishment (tahsiniyyah). In this study, the 'Investment' component of Family Takaful is selected to illustrate the above mechanics. Investments generate wealth. The five areas that need to be protected under essential benefit (daruriyyah) in order to maintain social order and stability are faith, life, intellect, family and wealth. Wealth is regarded as one of the fundamental and universal principles of the Shari'ah which must be protected and preserved for economic prosperity of the Muslim ummah and the general public.

Second Filter ("Maqasid of Wealth") To ensure a Just Distribution of Wealth
Family TakÉful is differentiated from General TakÉful by its wealth generating component. The
Family TakÉful Investment-linked Product is selected in this research, as it is wealth generating, and
comes under the scope of wealth protection. The maqasid of wealth itself has 5 criteria to ensure that
not only is wealth generated, protected and preserved but there must be a just circulation of wealth in
the hands of many people. The five universal values reflected in the second filter will enhance
transparency, conscious risk-sharing and informed choices, just circulation of wealth, and durability
for long term sustainability of the industry and the combined fulfillment of these values will lead to
economic prosperity according to the precepts of Shari'ah and social justice.

On maqasid of wealth, the 5 criteria that must be fulfilled to ensure economic prosperity and social justice are: marketability (rawaj); transparency (wuduh); preservation (hifz); durability (thabat); equity ('adl). As illustrated above, these parameters will be incorporated in the second screening. Specific issues identified in family takaful operations are used to determine whether the application of the maqasid filter, based on the above criteria, can help ensure not only halal profits but also the fulfillment of maslahah of a just distribution of wealth, clarity of products, growth and constancy and the attainment of sustainability goals to support future generations. When applied to family takaful operations, 'marketability' here means a fair circulation of wealth in the hands of as many people as possible. ${ }^{14}$ The maqasid that needs to be fulfilled here is to ensure that wealth does not circulate only among the wealthy (59:7). It is through this unique two-tier screening methodology that a deeper and wider audit will be conducted. Internal auditors will be disciplined to rank or prioritise the Takaful operational process (underwriting contracts and policies, investment, product development, distribution channels, corporate communication, information technology, human resource and expertise, etc) according to whether it is daruriyyat, hajiyyat or tahsiniyyat. The 'maqasid paradigm' and 'maqasid filter' will provide a framework to objectively and scientifically assess compliance to shari'ah 
objectives, and complementing existing audit framework which are already assessing compliances to shari'ah rules.

\section{Diagram 3: Operationalising the Maqasid using the "Maqasid Filter" on Family Takaful}

\section{RISK MITIGATION}

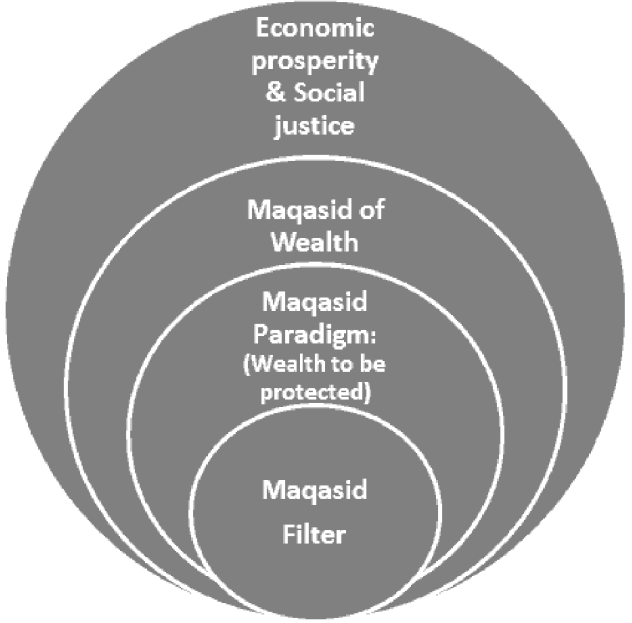

Source: Author's own

On a macro-level, the objective of marketability (rawaj) will act as a filter to ascertain whether the takaful products and investment avenues are designed to cater for only a small segment of society, the high-net worth individuals (HNWI), or are they accessible to the "have-not" individuals (HNI) for an equal opportunity to generate wealth. Internal auditors will also be disciplined to adopt a human-centric approach to audit and to measure Family Takaful operations" attainment of the higher objectives of the Shari'ah on economic prosperity and social justice. The maqasid filter will have a dual function of screening halal options and maslahah enhancements to give consumers the right to enjoy products that are lawful and good. The balanced approach of the maqasid-based audit, will assist the industry to overcome existing practice of "form over substance" (or legalistic compliance) to Shari'ah. An imbalanced shari'ah audit will result in the neglect of socio-economic justice which must be avoided. To summarise, the Screening Methodology can be applied in General and Family Takaful in the following areas:

a. At the governance level, a Shari'ah-compliance audit of organizational structure, people, and process and IT application systems will use the screening process to measure not only compliance to the rules of governance (including shari'ah governance), but will also measure the maqasid impact (benefit realization) of such rules to customers and other stakeholders in order to preserve their rights to a full and fair disclosure of the actual practices, which must have no conflict of interest situations, clear of any corrupt practices and prudent management of their investments;

b. At the operational level, the screening methodology functions as a filtering mechanism to ascertain whether the Investment-Linked Product developed by Family Takaful Operators is complying with the maqasid of economic wealth using Ibn OshËr's five parameters or criteria of marketability (rawaj); transparency (wudah); preservation (hifz); durability (thabat); equity ('adl).

The Screening Methodology will be applied by shari'ah officers and internal shari'ah auditors during the auditing of Family TakÉful operations. The Screening Methodology makes an additional assessment on shari'ah compliance from a purposefulness approach. It will realign the audit focus to a measurement of

14 Ibid

(c) COMSATS Institute of Information Technology Lahore, Pakistan. 
ethical objectives to complement current technical or legal audits. It is through this holistic and integrated audit focus, that the two objectives of the Shari'ah on social justice and economic prosperity will be accomplished by Takaful Operators.

\section{Conclusion}

Islamic finance has a diverse spectrum of Shari'ah contracts in financial transactions that provide for different risk and return profiles. By complying strictly with the legal specificities of the contract it will indeed preserve the sanctity and validity of Islamic financial transactions. However, what should be given further consideration is the ethical and religious aspect of the contract to achieve social justice, where the beneficial impact on humanity or welfare of the public should be the prime consideration. The regulator wants greater clarity on the legal and prudential requirements through the contract-based regulatory framework, (Zeti Akhtar Aziz, 2012); but if it is to be underpinned by the fiqhi contractual principles only, then the purpose of the Shari'ah will not be served; it may only enable IF system participants to align their practices and expectations accordingly in form, and not in substance when undertaking Islamic financial business and transactions. The framework may just be perpetuating the practice of a narrow audit focus - a weakness in the system that the industry should depart from. Jurists in their development of fatwa and ijtihad should always be guided by this divine blueprint on human welfare and restrain themselves from being too legalistic that the spirit of the Shari'ah is downplayed in the current "Shari'ah conversion technology". In the face of such a challenge, there are initiatives by scholars and practitioners to move beyond compliance, and to innovate, and not imitate or replicate. The Shari'ah Governance Framework has planted the seeds of change where eventually the comprehensive Shari'ah compliance governance in Malaysia will progress towards the higher goal of attaining a Shari'ah-based operating environment. It is envisaged that the maqasid approach may provide a solution to the credibility/differentiation challenge as faced by the Islamic finance industry today and Takaful industry in particular.

\section{Recommendations}

1. The "Shari'ah Standards" issued by SAC should incorporate the ethical and religious standards or the maqasid of every contract to reflect its true nature.

2. It should be made a public policy requirement that Shari'ah decisions on product development must take into consideration both the legal and maqasid impacts.

3. Takaful audits should adopt a balanced Shari'ah audit where assurances are given to the public that takaful companies are complying with the ethico-religious requirements and a prudent management of their wealth according to shariah rules and objectives.

4. The Screening Methodology is an exploratory study which should be researched further by regulators and the Takaful industry, as a mechanism to operationalize the maqasid and give fuller protection to consumers whilst assuring the public in a scientific way that it is a holistic and integrated Shari'ah compliance audit.

\section{Bibliography}

AAOIFI (Accounting and Auditing Organisation for Islamic Financial Institutions, 2010. Shariah and Audit Standards.

Azman Ismail 'Regulation, Governance \& Risk Management Issues in the Family Takaful Market. IIFIN Consulting Sdn. Bhd. 2011

Ibn Ashur Treatise on Maqasid al-Shariah. Translated from the Arabic and Annotated by Mohamed El-Tahir El-Mesawi. The International Institute of Islamic Thought. Joint publication with Islamic Book Trust. 2006

Islamic Insurance: Trends, Opportunities and the Future of Takaful, Edited by Sohail Jaffer. Euromony Books, 2007

Mohammad Hashim Kamali. Occasional Paper series 'Maqasid Al-Shariah Made Simple'. The International Institute of Islamic Thought. 2008

Shariah Governance Framework for Islamic financial Institutions for Islamic banks and Takaful Operators. BNM/RH/GL_012_3 (2011).

Syed Othman Alhabshi \& Shaikh Hamzah Shaikh Abdul Razak 'TAKAFUL: Concept, History, Development and Future Challenges of its Industry.

Takaful Act 1984 (Act 312) and Regulations. International Law Book Services, 2007

Takaful Islamic Insurance. Concepts and Regulatory Issues. Edited by Simon Archer, Rifaat Ahmed Abdel Karim and Volker Nienhaus. John Wiley \& Sons Pte. Ltd. 2009

Tobias Frenz \& Younes Soualhi Takaful \& Retakaful: Advanced Principles \& Practices. Second Edition Published in collaboration with Munich RE. IBFIM KL, 2010.

Zuriah Abdul Rahman \& Hendon Redzuan Takaful. The 21st Century Insurance Innovation. McGrawHill. 2009

c COMSATS Institute of Information Technology Lahore, Pakistan.

Vol. 2(1), 2017, pp. 24-33 
